Miss LAmb, before dealing with her own excavations on the newly discovered site at Kusura, which began in 1935, pointed out that recent archæological investigations in Anatolia had deduced from the surface examination of prehistoric mounds and the excavation of two or three large sites, that during the Bronze Age two main cultures were to be distinguished, of which one, a western, had affinities with Troy, and the second, a central and eastern culture, was marked by the principal Hittite remains. Kusura lies on the southernmost of three routes from east to west of which one extends to Troy, the second to the coast near Smyrna, while the third, with which she was concerned, traverses the upland plains south of Afyonkarahissar. The town itself, it would appear, was occupied for the first time about the end of the fourth millennium B.c. A cemetery yielded pottery markedly local in character, unlike anything found elsewhere in Asia Minor. This strongly marked local character in the culture Miss Lamb found to persist even at the end of the Bronze Age, when there were signs of Hittite influence as well as of connexions with Troy. Further evidence relating to the "indigenous' culture and its contacts with east and west will obviously be of considerable interest, especially in view of the results obtained by the Neilson Expedition at Serkeli, where also, judging from the preliminary report, there appears to be a strongly marked local culture. This is clearly of considerable antiquity, as it underlies levels which correspond with the earliest culture of El Obeid and Arpachiyeh in Mesopotamia. The stratum in question is said to be nine feet thick and to lie at a level of twenty-five feet below the Hittite levels. Its distinguishing feature is a peculiar painted pottery and plain pottery, while obsidian and flint were in use.

\section{Promotion of International Equity}

A PRELIminary outline of the proposals of the New Commonwealth Society for the creation of an equity tribunal for the settlement of non-justifiable disputes between nations is contained in a pamphlet, "An International Equity Tribunal", which has just been issued by the Society. It is urged that three institutions are required: (1) a body endowed with the legislative function and with the power to effect peaceful changes in the public law; (2) a court to interpret that law; and (3) a police force to uphold the decisions of the Court and to maintain law and order. The League of Nations is considered the foundation upon which the structure of an enduring peace is to be built, and these institutions should form part of its permanent machinery. By an equity tribunal is meant an impartial or neutral body which is called upon to investigate a political or industrial dispute, and the findings or awards of which are based upon natural justice. Consequently an international equity tribunal would be capable of effecting peaceful change in the public law, including the revision of treaties, and would be empowered to arbitrate upon all political disputes which cannot be settled by negotiation and conciliation. The members of the equity tribunal would require to sever their connexion with the Governments and politics of their respective countries and devote their time exclusively to the service of the tribunal and of the League. An embryonic example of the working of an equity tribunal may be seen in the Lytton Commission, and a further stage towards the develop. ment of the tribunal system would be the creation of permanent committees by the Council or the Assembly in place of such ad hoc bodies.

IT is suggested that the formation of an equity tribunal with a permanent and independent status, with members elected in the same way as the judges of the Permanent Court, is likely to provide the most effective machinery for the adjudication of political disputes and the revision of treaties. Its addition to the machinery of the League would disarm the assertion of certain non-members that the League is simply a vehicle for protecting and sponsoring special interests. The tribunal would be related to the Permanent Court, possibly as an independent division, with a personnel not consisting mainly of lawyers, and enforcement of its awards in the last resort would be secured by the existence of an international police force. The pamphlet is obtainable from the New Commonwealth Society, which has established itself as one of the most active organizations working in the field of international peace. Particulars of its work and conditions of membership can be obtained from the Secretary, Thorney House, Smith Square, Westminster, S.W.].

\section{Organization in Petroleum Research}

RESEARCH is necessary in practically every phase of the petroleum industry to-day and, in view of its importance, should be prosecuted in the most efficient and economic manner possible. In a paper read before the Institution of Petroleum Technologists on December 8, J. H. Vermuelen discussed the organization of research. The main point to which he directed attention was that although decentralization is inevitable in every petroleum company owing to its very nature, yet its technical and administrative activities should be controlled and guided by a central laboratory. The laboratory should be so designed and equipped that routine and ordinary research can be carried out at the same time as applied and pure research and, while there should be no interference between the two types of research, yet there should be ample facilities for exchange of ideas. The routine function of the central laboratory should be to collect technical and commercial data from all branches of the company, systematize it and render it available in a convenient form for reference.

Ax the same meeting of the Institution, W. C. Asbury and D. A. Shepard threw further light on the organization of research by a description of methods adopted by the Standard Oil Co. (N.J.). Since its inception, sixty-five years ago, the company has been engaged continuously in research, and has had to meet the diversified interests and needs of several hundred subsidiary companies. Its technical 
organization has grown on lines which combine centralization and decentralization. Problems peculiar to one operating unit are studied in laboratories controlled by that unit, but in addition all operating units are served by a commonly controlled central staff organization which incorporates research and development laboratories and co-ordinates the technical, scientific and patent activities of all units. Further, it has long been the practice of the company to support research programmes in special fields in university laboratories and to give recognition to the contributions to petroleum technology made by scientific workers and technologists. This is perhaps the most striking manifestation of the necessity felt by petroleum companies for some form of decentralization and external collaboration.

\section{Calf of Man as Nature Reserve}

Mr. F. J. DrCKENs of Silverdale, Carnforth, Lancashire, is presenting the Calf of Man to the National Trust. This gift should prove a very valuable addition to the island bird sanctuaries of the British Isles. The Calf, with the rocks to the south of it and Chicken Rock Light, have provided invaluable facilities for bird migration study, and as it is proposed to have the property managed by a committee of ornithologists and Manxmen, there is a unique opportunity for erecting another ringing station or bird observatory of the Isle of Man and Heligoland type there. Covering some $616 \frac{3}{4}$ acres, more than four hundred of which are healthy pasture, and including steep cliffs, a marsh, farm, ponds, a dam, and a glen, the Calf of Man as a bird reserve would preserve the nesting sites of some thirty species of bird including such birds as the chough which, declining in Cornwall and Devon, is increasing in the Isle of Man, the peregrine falcon, the shag, puffin, guillemot, razorbill, raven, kittiwake, rock-pipit, etc. There is a farm where a few house-sparrows, starlings, and blackbirds find a living, and wrens inhabit the caves. On migration, many warblers visit the Glen, etc., and forty-eight species of birds have been noted at the Chicken Rock Lighthouse (so named by sailors from the abundance of the storm-petrel or Mother Carey's chicken off that low rock). There may no doubt be need for some scientific control of the bird numbers, as in recent years the greater black-backed, lesser blackbacked and herring gulls have increased their nesting areas, and these rapacious birds are often a danger to more interesting, but less vigorous, species. The flora has not been worked so thoroughly, but some three hundred or more plants occur, including the yellow-petalled 'ochrocyanea' variety of wild radish near the farm, wild hyacinth in a curious marshland habitat near the landing Sound, and sundew.

\section{Bird Migration and Air Currents}

AT the annual conference of the International Faculty of Sciences, held in London on January 29-30, Capt. B. Acworth presented a paper entitled "New Light on Bird Migration". But the paper contains nothing of importance that was not set down lucidly and with similar diagrams in his "This
Bondage" in 1929. There is the same useful insistence upon the effects of wind currents upon the movements of birds, and alas, the same errors are repeated. For example, Capt. Acworth insists that the permanent winds of the tropics form impassable barriers; that consequently "the species of birds found in particular temperate zones must have had separate origins" ; and that these facts "seem to demolish ... . the theory of evolution as it affects the common origin of birds." But surely the fact that every autumn and spring in the Old World and the New birds do actually cross, as a matter of routine, the "impassible barrier" of the equatorial currents demolishes the whole argument. Again, the exact knowledge of the writer of the Book of Exodus in describing how "the east wind brought the locusts" is contrasted with the ignorance of biologists, anatomists and embryologists ; but records of insect migrations show that the wind is not the directive factor in a large percentage of cases. Lastly, "seasonal winds have always ensured the translation of birds to parts of the world agreeable to the essential needs of the appropriate species", which, if it means anything at all, means that wind and no biological factor has settled the agreement between birds and their environment.

\section{Agriculture in Tanganyika}

THE annual report of the Department of Agriculture in Tanganyika for 1935 has now been published (Dar-es-Salaam : Government Printer, 1936). From the economic point of view, the past five years have been the most critical in the history of the Territory, and 1935 can be regarded as the culminating point of the effort to place it in a position of economic security. The volume of total exports attained has never before been approached, in spite of the fact that record figures for most crops had been reported during the four previous years. In the year under review, records for the export of the three premier industries, sisal, cotton and coffee, have been achieved, while high figures are again reported for ground-nuts, bees-wax and sesame. Copra alone has yielded disappointing results. The soundness of the policy of increasing production in a territory which has not reached the limits of development seems to have been vindicated, as the standard of living and purchasing capacity of the native peoples have been markedly improved, and also a rise in the value of exportable commodities obtained. As regards non-native agriculture, the excellent price secured for sisal-hemp stimulated the rejuvenation of estates, re-equipment of factories and a general re-organization of the industry. Much too large a proportion of planters, however, still rely on a one-crop policy, and the adoption of a more diversified farming is advocated. Native development is making sound progress, successful concentration of population now being possible in districts which quite recently were povertystricken tsetse areas. Questions of irrigation and natural water supplies play a vital part in African life, and important developments are already in hand following the recommendations of the special inquiries completed during the year under review. 